\title{
A Cry for Help: Suicide Attempts by an Iraqi Refugee and the Role of Community Service Learning
}

\author{
Jennifer T DCruz ${ }^{1}$, Joanne N Joseph ${ }^{1}$, Nourhan Shehata ${ }^{2,3}$, Doug Gruner ${ }^{4,5}$ \\ All authors contributed equally. \\ ${ }^{1}$ Faculty of Medicine, University of Ottawa \\ ${ }^{2}$ Registered Member of the Egyptian Medical Syndicate \\ ${ }^{3}$ Faculty of Medicine, University of Alexandria \\ ${ }^{4}$ Family Medicine Centre, Bruyere Hospital \\ ${ }^{5}$ Department of Family Medicine, University of Ottawa \\ ABSTRACT
}

Community Service Learning (CSL) is a method of teaching where students learn through active participation in thoughtfully organized community service. CSL has emerged as a promising training method to address the changing needs of medical students and to improve their social accountability $(1,2)$. Medical schools are beginning to incorporate community service learning into their curriculums as a way to introduce students to the complicated world of delivering care to vulnerable populations.

Mr. A, a refugee from Iraq, immigrated to Canada in June 2015 with his family. Five months later, during a CSL medical intake interview with two medical students and an Arabic interpreter, he revealed to have ongoing suicidal ideation and multiple suicide attempts. Due to significant cultural taboos and stigma around mental illness, Mr. A was initially very hesitant to seek medical help. However, with the help of the CSL program he was able to get much needed medical care.

\section{RÉSUMÉ}

L'apprentissage par le service communautaire (ASC) est une méthode d'enseignement où les élèves apprennent en participant activement à un service communautaire bien organisé. Le CSL est une méthode de formation prometteuse pour répondre aux besoins changeants des étudiants en médecine et pour améliorer leur responsabilité sociale $(1,2)$. Les facultés de médecine commencent à incorporer l'apprentissage par le service communautaire dans leurs programmes d'études afin d'initier les étudiants au monde complexe de la prestation de soins aux populations vulnérables.

Monsieur A, un réfugié d'Irak, a immigré au Canada en juin 2015 avec sa famille. Cinq mois plus tard, au cours d'une entrevue d'admission médicale CSL avec deux étudiants en médecine et un interprète en arabe, il a révélé avoir des idées suicidaires en cours et de multiples tentatives de suicide. En raison de tabous culturels importants et de la stigmatisation entourant la maladie mentale, Monsieur A était initialement très hésitant à demander de l'aide médicale. Cependant, avec l'aide du programme CSL, il a pu obtenir des soins médicaux indispensables.

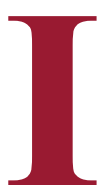

Increased rates of Post-Traumatic Stress Disorder (PTSD) and depression among refugees in Canada is of concern $(3,4)$. This trend of increased mental health disorders can be attributed to pre-migratory, migratory, and post migratory stressors related to finance, shelter, education, and health (5). Hence, family physicians, as primary care providers, should be well equipped with the tools necessary to recognise, assess, and treat mental health issues present in vulnerable populations. One such tool is the awareness of cultural stigma towards mental health disorders and the ability to provide unprejudiced care on the basis of a trusting patient-physician relationship (3).

\section{CASE DESCRIPTION}

Mr. A, a 38-year-old Iraqi refugee arrived in Canada in June with his wife and 3 children. Approximately 5 months later the family was paired with 2 medical students and an International Medical Graduate (IMG) Arabic interpreter for a Medical Intake Interview as part of a Community Service Learning (CSL) placement. Mr. A stated he slept poorly - often sleeping only 2 hours a day and smoking 4 packs of cigarettes daily. He said his only goal was to bring his children to Canada, away from the war torn area in Iraq. Now that his mission was accomplished he felt his job was done and had no desire to pursue a career in Canada. His family commented that he was sad all the tme, and he had lost interest in friends and activities. Despite being diagnosed

Keywords: Community Service Learning; Refugees; Mental Health 
with depression a few months prior and taking antidepressants, Mr. A did not feel any better.

Mr. A did have a history of depression in Iraq and disclosed sustaining multiple gunshot wounds to his left leg during the war. His leg was not treated by a medical doctor at the tme of injury due to his immense distrust in the Iraqi medical system. Although there was no infection in the leg, currently it remained painful to walk, and he admitted to engaging in self-mutilation, where he intentionally peeled his own skin. The combination of his self-mutilating behaviour, poor sleep patterns, loss of interest in life, and depression prompted the question: "Have you ever had thoughts of suicide?"

Mr. A disclosed that he did have thoughts of suicide for many years and had already tried committing suicide, as recent as 2 weeks ago in Canada, by electrocution. During the conversation, he was suicidal and had no desire or hope to live through the night. He stated, "I would rather die than to let anyone know about this [suicidal ideation]" and asked the medical students and interpreter not to tell his family. Throughout the conversation Mr. A had a very calm demeanor, but he was visibly unhappy and teared up occasionally. A family doctor, who is also the advisor for the CSL program, was immediately consulted and had advised that Mr. A's case was urgent and required an immediate visit to the Emergency Department (ED). As stigma around mental health issues persist, and more so in Arab cultures, Mr. A initially refused to go to the ED in fear that he would be admitted to the hospital, causing his family to find out about his mental illness. After much reassurance and encouragement by the interpreter, family physician, and medical students, Mr. A agreed to go to the ED provided that the interpreter and medical students accompanied him.

At the ED, Mr. A revealed details of trauma which included witnessing the death of his brother as well as his best friend. Mr. A refused the assistance of a male Arabic interpreter in the ED and stated he felt that he was being "judged". He insisted on the presence of someone he was familiar with. Therefore the CSL interpreter and then Mr. A's settlement counsellor took turns assisting the ED staff with translation during Mr. A's interview. Later, Mr. A was discharged home with a prescription for antidepressants and a referral to a psychiatrist. Mr. A makes weekly visits to his psychiatrist with good progress. His family physician was also updated on this incident and is following up with Mr. A more frequently. He is currently keeping very well and is able to sleep for a longer duration with significantly decreased suicidal ideation. He is able to spend more tme with his family and is reconnecting with other Iraqi friends.

\section{DISCUSSION AND CONCLUSION}

Refugees are often marginalised and unable to access health care effectively. Those with pre-existing conditions like depression are most at risk. As this case illustrates, mental illness is often stigmatized among refugee families - often leading to refugee patients dealing with their illness in isolation, without any family support. PTSD has been reported in many refugees, making integration into the new community even more difficult. The University of Ottawa CSL program aims to support settlement agencies in providing assistance as well as a bridge to primary health care for refugee families.

CSL provides a unique opportunity for medical students to gain confidence and competence in communication skills, advocacy, and collaboration with community agencies and other healthcare workers. It also carves out space outside the traditional classroom to allow students to build trusting relationships with often vulnerable and marginalized populations like refugees. Refugees are able to experience health care via CSL in a gentler, less intimidating way, thereby often leading to more positive outcomes.

Developing and maintaining the trust of Mr. A was crucial to him disclosing his suicide attempts and proceeding to the ED to seek help. The students and Arabic interpreter continued to visit Mr. A and his family at their home. The sense of being welcomed by the students clearly has had a profound effect on Mr. A as he continues to do well from a mental health perspective. The fact that our Arabic interpreter was an IMG helped us tremendously in this situation. For example, her past medical experience helped her to quickly identify the signs of a major depressive episode, PTSD and suicidal ideation while simultaneously, she was able to apply her own personal cultural knowledge to delicately delve deeper into Mr. A's story to develop a trusting rapport in a culturally competent manner. This is an example of how IMGs, in the context of new incoming refugees, can have a vital role as part of a refugee family's circle of care.

In conclusion, CSL provides early learners with the experiences of working with vulnerable populations, which has the potential to not only lead to more social accountability amongst health care providers, but also the creation of physician leaders. 


\section{KEY POINTS}

1. Experiential, community-based training should be an integral part of medical students' education to learn the social determinants of health from the perspective of vulnerable populations. 2. Improved mental health education is required for refugee families, as well as increased resources to support their mental health needs.

3. IMGs can be a valuable addition to the preventative healthcare team for overcoming cultural and language barriers when interacting with refugees or immigrant families.

\section{REFERENCES}

1. McIntosh S, Block R, Kapsak G, Pearson T, Kaiser A. Training students in community health: a novel required fourth-year clerkship at the University of Rochester. Acad Med. 2008 April; 83(4):357-64.

2. Buck DS, Monteiro FM, Kneuper S, Rochon D, Clark DL, Melillo A, et al. Design and validation of the health professionals' attitudes toward the homeless inventory. BMC Med Educ. 2005 Jan;5(1):2.

3. McKenzie K, Hansson E, Tuck A, Lam J, Jackson F. (2009). Improving mental health services for immigrant, refugee, ethno-cultural and racialized groups: Issues and options for service improvement. Calgary, AB: Mental Health Commission of Canada.

4. Porter M, Haslam N. Predisplacement and post-displacement factors associated with mental health of refugees and internally displaced persons: a meta-analysis. JAMA. 2005 Aug; 294(5):602-12.

5. Ringold S, Burke A, Glass R. Refugee Mental Health. JAMA. 2005 Aug; 294(5):646. 